\title{
Nationalism in the Muslim World and the Identity Crisis: A Sociological Perspective
}

Jakir Al Faruki*

\begin{abstract}
Nationalism is a core phenomenon in the modern political world on which the state is established and functioned, at least most of the stakeholders argued. In the contemporary Muslim world, the sociopolitical concept comes to the Muslim youths as the most influential as well as vague ideological term in the political sphere. Sometime they confused with explaining the idea especially, comparing with Islamic interpretation of nationhood and nationality. This article investigates the prevailing condition of the explanation about the concept in the Muslim world and makes an effort to analyze it with the sociopolitical ground reality in the globally communicated growing young generation. In addition to this it undertakes an effort to clarify ambiguous understanding about the concept in Islam, sometimes which placed to encounter Islam as global sociopolitical phenomena. It is entirely an academic analysis of the concept considering current global perspective of the Muslim community.
\end{abstract}

Keyworlds: Nationalism, Kleptocracy, Asabiyah, Wataniah and Ummah.

\section{Background}

Nationalism is one of the major social phenomena that stirred the social and political thinking during $19^{\text {th }}$ and $20^{\text {th }}$ centies over the world and the Islamic world was not kept outside this reality. Nationalism influenced the social and political world in a both-way process. After the decaying influence of feudalism and theocratic Roman Catholic Church state in Europe, nationalism has got momentum in the hand of sovereign autocratic monarchs e.g. Napoleon (1804-1814) and Louis XIV(1643-1715) in France, Frederic (1888-1888) and Bismarck (1868-1890) in Germany, Mazzini (1805-1872) in Italy, Catherine (1762-1796) in Russia, Charles III(1716-1788) in Spain, Henry the XIII (1509-1547) in England and so on in one hand. On the other their expansionist policy of imperialism and colonialism needed popular support from the people for their despotic rule and absolutist government. Therefore they incite the

* Jakir Al Faruki, Assistant Professor in Sociology, Rajshahi Government College, and PhD Research Fellow, Jahangir Nagar University, Bangladesh. E-mail: ilham.faruki@gmail.com 
sentiment of the people in favor of their lust for absolute power and to continue imperialist expansion that provided them unlimited wealth that made happy the elites of the society. Moreover, two types of social and philosophical thinking processes helped nationalism grow more.

These are (i) the thinking of Machiavelli (1469-1527) of Italy, Bodin (1529-1596) of French, and Hobbes (1588-1679) of England advocated for unrestrained absolute power for despotic kings. Those (ii) who from the religious leaders opposed the Holy Roman Church state also reinforced the absolutism by their encountering religious theory of reformation. They are Martine Luther of Germany and John Wycliffe in England who upheld the divine right of kings to disendow the church (Swain, 1994: 384). Luther wrote, 'It is no wise proper for anyone who would be a Christian to set himself up against his government whether it acts justly or unjustly' (cited in Swain, 1994: 384). They still believed the sources of all power to be God and entrusted to the king. Dante, the great poet, supported such notion. According to the above discussion the following points are the historical causes of rising nationalism in Europe. The extreme form of nationalism that people observed in human history is fascism in Italy and Nazism in Germany that caused a huge loss of lives and wealth in the World War I and II as well.

In addition to that in $17^{\text {th }}, 18^{\text {th }}, 19^{\text {th }}$ century major bloodiest wars occurred for nationalism or national pride or nationality feelings. The social background of rising nationalism is mentioned below:

1. The declining influences of feudalism and Church state over all sphere of society;

2. The rise of absolutism and despotism in politics and government;

3. To gain support for expansionist policy of imperialism and colonialism from the people;

4. Rationalism for absolutist state by social and political thoughts;

5. Rationalism provided by religious explanation of Protest thinking antagonist to Catholic Church state;

6. Conflict of controlling power and wealth between state and divine Catholic State

Through these background realities in the middle of the ninetieth century nationalism became the dominating social and political driving force in Europe. Nationalism propelled the expansion of imperialism and colonialism in various continents especially in both parts of America, Asia, Australia and Africa. In the beginning, Europeans expanded their colonies through sea to air, from the one pole to the other and at the end of the mid twentieth century colonized people sped up their freedom movement from the burden of colonialist yoke and imperialist invasion inspired by the nationality feeling. So historically nationalism plays its role in both ends of the process of imperialist invasion in the point of start at the invaders' end and freedom 
struggle of independence loving people in the finishing side. Both were inspired by nationalism by thinking that it is the force which can easily inflame the sentiment of the people for any war or movement against any political power. For this reason in early twentieth century almost all the Muslim territories and communities under the imperialist rule were greatly influenced by their western educated leaders who were deeply motivated to the ideology of nationalism.

\section{Muslims' Experience}

By the mid of the $19^{\text {th }}$ century almost all of the Muslim territories and population went under the European colonial rule and retained under the imperialist government for one hundred to three hundred years. All along the period of colonial rule the colonial masters not only looted, smuggled and transferred their wealth but also destroyed their social infrastructures and institutions as a whole. In that circumstance newly born European educated small elite groups and a small group of Islamic educated people were thinking that nationalism can be a proper means to acquire power from, at least sharing power with colonial masters. This is the starting point of nationalism in the Muslim world. These small elites started nationalist movement sometimes cooperating with the colonial masters (Indian Nationalist Congress or Muslim League in India), sometimes confronting with the masters and sometimes using both processes in a cleverer way. The leaderships promised to the people to gift them democratic state, rule of law and economic emancipation through the independence from the yoke of colonialism by sacrificing a little of their lives, wealth and pains. People sacrificed not a little, in some cases a lot or everything for the promised democracy, rule of law and economic emancipation through independence struggle. In the pledged national state they got, almost all the cases, more repression, despotism, autocracy, kleptocracy, misrule, fascism, exploitation, omnivorous corruption, smuggling and transferring public wealth from their own peripheral country to ex masters' centre country. It is the irony of fate for the colonized people accomplished for their invaluable sacrifice in the freedom struggle.

The leaders of independence struggle almost failed in all respects, especially, in the effort of nation building and state building. Kamal Ataturk became the worst despotic leader in Turkey. Jamal Abdul Naser in Egypt, Benbella and Benjadid in Algeria, Sukarn in Indonesia, Habib Boguiba in Tunisia, Saddam Hossain in Iraq, Gaddafi in Libya, Reza Shah in Iran are the worst examples of fascist and autocratic nationalist rulers among others. They were oppressive to their opponents, corrupted and patronized wholesale corruption in all levels and destroyed all signs of democratic institution that was planted by European colonial rulers. Their wishes and desires 
become the highest law of the state and in some cases economic sufferings of people went up to the highest. They failed in all respects of (1) nation building and (2) state building process. They divided people by many false identities and labeled them many ideological colors. They killed their own people large in number than those of the colonial rulers. All the malpractices they have done in the name of nationalism, patriotism, national interests and national security. By experiencing such situation a large section of people are frustrated with that type of nationalism and the nation state, therefore they are searching for new ideology for the state. For this, some hugged Marxism or communism and some are inclined to Islamic revivalism.

\section{What is Nationalism?}

Nationalism is a feeling which is intensely related to the idea of nationality and nation state. How is a nation born is not easy to explain in all cases. However, the consequence of internal current of consciousness of a group of people, their consistent continuation, collective traditional resources and cultural integrity for a long period of time is nationality. It is an abstract consciousness that is achieved through the historical journey and cherished in the mind of every individual in a group. It is a tenet, a consciousness or the name of feeling that evolved and developed centering by a group of people. Nationalism is, according to MacIver, a type of community sentiment, a sense of belonging together, created by historical circumstances and supported by common spiritual possessions of such an extent and so strong a group that those who feel it desire to have a common government particularly or exclusively of their own (MacIver, 2005). Nationality is related to tribal life that is an extended family or clan. Common cultural tradition stimulates the nationality feeling and it is rooted in the territorial living. It is to be noted that nation is a geo-political reality and nationality is psycho-social construction. Laski opined that the idea of nationality is essentially spiritual in character. When a group of people with deep feeling of nationality and commonness living in an integral territory, creates an independent state or desires it, then a nation gets existence (Laski, 1925: 218-231). In addition, C J Hayes outlined that a nationality by acquiring unity and sovereign independence become a nation. Lord Bryce opined that, a nation is a nationality when it has organized itself into a political body, either independent or desiring to be independent (Bryce, 2008). So, it can be said that nationality is a consciousness, a state of mind and its final consequence is nation.

Nationalism is a feeling of a group of people, their consciousness about 'collective entity' and philosophical expression of own self. It is a modern fusion of exaggeration of two very old phenomena of nationality and patriotism. It is an invisible entity 
which is difficult to define by one or more specific elements at all. Hans Kohn said that nationalism is first and foremost a state of mind and act of consciousness (Kohn, 1994: 03). In fact, Nationalism arises through a long period of living together of a group of people, mutual exchanging of ideas, participating in same kind of productive activities, sharing of long time experiences, nourishing unified reminiscence of glory and pride. L. L. Snyder mentioned in this respect that nationalism is a product of political, economic, social and intellectual factors at a certain stage in history, a condition of mind, feeling or sentiment of a group of people living in a well-defined geographical area. The idea of nationalism and that of nation state are almost inseparable from each other. It is evident that sometimes nationality came into being from a state; on the other hand, sometimes a nation state is the child of national movement. For example, there is a feeling and idea of a single nation of a people, living in a single territory, sharing same life style and then culture gives birth to the nation state Bangladesh in 1971. On the contrary, there were no nations naming Kuwaiti, Qataris, or Saudis before the birth of those countries. In Africa and Latin America there are many countries which got independent from colonial legacy as administrative area and then nationality feeling was born after crating those state (Bottomore, 1994: 99). Sudan got independence from colonial master as single nation, then South Sudan was separated from mainland by religious identity, Taiwan and China were inseparable part of a same nation but separated by ideology. Vietnam, Yemen, Korea and Germany are the few examples that proved nationality is not a permanent idea and feeling of men. Elements of nationality are not the same in all cases. But the most common following factors are found over the world as constituent of nationality. These are:

1. Common past, tradition, culture, life style;

2. Common language;

3. Common belief, religion (Hindu or Muslim) and ideology; \{Communism, Islamism, Socialism (Nationalist-Taiwan, Socialist-China)\};

4. Tribal past, kinship, Clan, blood relation, physical characteristics, color, race;

5. Territorial Integrity and cohabitation;

6. Living experience of dwelling under the same administration as an identical administrative unit (for example, a province under the rule of British Indian government;)

7. Living under a sovereign state in a common geographical location; 
We may classify point 1-3 as ethnicity or culture, point 4 as racial element and 5-7 as the geo-political elements.

Presence of one or more or all factors for a span of time period does not ensure long lasting or permanent feeling of nationalism in a given people. A part of Assam's people are more Sylheti than Indian or Assamis considering culture, traditions, life style and language but they are not sylheti or Bangladeshi, they are Indian by nationality and even they do not claim themselves as Bangladeshi. Residents of Kolkata and Dhaka have the same administrative past with sharing the same language and culture but since 1947 they became the part of separate nations and their ideas of nationalism are of course different. The Canadian, the Australian, the American and the New Zealanders are speaking in the same language but they are not sharing the same feeling of nationalism. At present only a group of people in a sovereign state based on geographical integrity is the only determinant that becomes the defining fact for nationalism.

\section{Islam and Nationalism}

Islam neither advocates for the strongest nationalism nor takes hard core stand against nationalistic feeling. Islam is well aware about the pros and cons of human nature. As nationalism is a changeable group feeling interacting with many other socio-political factors so Islam's position is well thought out prone to permanent solution. Islam respects all the natural human feelings including nationality and patriotism very much (Zaman and Shahzad, 2012) but designs the society based on universal welfare of humanity for achieving the ultimate objective of unity of man that is the core principle of Islam. At the same time Islam never allowed destructions done in the name of extreme nationalism or chauvinism e.g. that humanity experienced in the World War I and World War II and so on. Islam is very much liberal about all the group relation regarding family, blood, cultural, political and geographical for the group identity of man respecting their love and passion for fellow people. The Qur'an narrates that 'Men, we have created you from a male and female and divided you into nations and tribes that you might get to know one another, the noblest among you in Allah's sight is he who is most virtuous among you' (Qur'an, 49: 13). According to this verse Islam implicates three principles about nationality and group identity. These are:

1. Distinctive character of group identity regarding any type of 'we feeling' are respected and encouraged in Islam as there is group identity e.g. love for family and clan, passion for community or territorial group, feeling for group regarding lingual identity or affection for sovereign state or so on. 
2. The final identity is 'man' as all are sons and daughters of one man and woman; they were the beloved creation of Allah and were the devout servants of Allah. All men are the members of the same nation in broader sense so that there is no scope for dividing humanity in narrow interests or identity that ultimately causes conflict among them, the history of humanity is full with such examples of conflicts and bloodsheds.

3. Those pride and arrogance that come from national identity is valueless in Islam, rather perfection and devotions in good deeds are only the standard for valuing man. Human being should be judged by their performance, not by their group identity in any form e.g. blood, clan, culture, language or citizenship.

These three dimensions are the full support for fulfilling the objective of building the universal community of ideological brotherhood that is based on faith and value system. In another verse, the Qur'an narrates '...you all are the members of only one nation and I am your only Lord, men divided themselves in schism...' (Qur'an, 21: 92-93). Again Islam puts balance in perfect centre point- Islam respects the group identity of any kind but not support schism that ultimately raises quarrel and conflicts. Man's prime target is living with meaningful peace not dying by conflict or chaos for identity crisis. Islam laid down nothing in obscurity rather declared in lucid tone 'You are the nation of Abraham, he (Abraham) is the father of your nation, and he named you Muslims' (Qur'an, 22: 78). It is a clear cut massage from the Qur'an that the Muslim is a single trans-boundary group founded on the faith and values. The group stand on the middle in all respects and the goal of the nation is to build a livable and peaceful world for the humanity that Allah almighty desired when he expressed his wish to the angels that He wanted to send His representatives (man-with no divisive identity) in the earth.

In the Qur'an the three terms are found almost similar to the idea of nation; these are: (1) Millat; (2) Qoum and (3) Ummah. Ummah and Millat implicate broader sense of nation and Qoum denotes community, clan, tribe, organization, association and sometimes nation but its common use is for community and clan. Nationality feeling or state of mind is described by three terms: Al Asabiyah (solidarity feeling for community or clan), Al Qoumiyah (solidarity feeling for clan, group, nation, party, organization) and Al Wataniah (love and passion for homeland or country). Asabiyah and Qoumiyah is something related to clan or community feeling of solidarity and Wataniyah is something related to geopolitical group solidarity. Islam takes all of the feeling as positive group force until they surpass the feeling of solidarity centered with value and system of beliefs (Zaman and Shahzad, 2012). 
A debate on nationalism is an endless one in Islamic world from the late $19^{\text {th }}$ century AD date. We can classify the debate in the following category:

1. Western Nationalism: Nationalism influenced by modern western educated thinkers and philosopher centered by territorial group entity or geopolitical identity that is homeland, culture is the base, especially language e.g. Indian Nationalism, Arab Nationalism, Turkish Nationalism and so on.

2. Muslim Nationalism: Nationalism centered by Transboundary Muslim Identity. It is emerged in the late nineteenth century among the Muslim scholars and youths in a transitional crisis point of the history of Muslims over the world. Jamal Uddin al Afghani (1839-1897) and the great philosopher and poet Allama Iqbal (1877-1938) were the pioneers in this school of thought. The core idea of thinking is all Muslims are members of a single nation and they need to create a sate for Muslims as first steps.

3. Nationalism not accepted: No nationalism is accepted according to their view. They are in the argument that any idea of nationalism ultimately degrading the idea of global unification and welfare of the humanity. And such idea flourishes schism in the mind of people and ultimately tends to everlasting conflict among the nations. Sayyid A. A. Maududi (Maududi, 1986), Maryam Zameela (A Palestinian writer) are, among others, supporters of this view.

Let us discuss in brief these three types of nationalistic idea in Muslim society. Through the past century not only Muslims have been involved in argument with each other but also warring with each other in some cases. If world Muslims want to concentrate to their overall interests they need to confine this debate in the academic arena and develop a consensus about their present socio-political interests and future aspiration.

1. Western Nationalism: The idea of western nationalism has been obscured by many realities and changing over the course of time by the changing socio political realities. It seems western nationalism is based on homeland; then what is the boundary line of a homeland and what is its definition? Is it Germany then where were the East and West Germany? If it is East Germany then now where is it? If it is India where was Pakistan, if it is Bengal why is it divided? If it is Punjab then how are East and Western Punjab born? If it is Yugoslavia then where were the BosniaHerzegovina, Croatia, Montenegro and Serbia? If there is the fundamental point of language, then what is the reason of the birth of a host of nations in the Middle East that is in the area of Arabic speaking people? Then the valid question is that only 
definition of homeland is what is set or formulates the colonial or imperial masters as their convenience or wish?

This is the obscurity of nationalism that is not resolved yet through the history of three centuries journey of nationalism. The Western educated Muslim scholars, political elites and politicians are inspired by the $19^{\text {th }}$ and early $20^{\text {th }}$ century concept of nationalism. Abul Kalam Azad, Humayoun Kabir in India, Kemalist in Turkey, Nasserist in Egypt and so on advocate for geopolitical Western Nationalism, Kemalists stand for some kind of ethnocentric nationalism that is Turkish language and Turkish ethnicity. Egyptian Rafi al Tahtāwi (1801-1873), Mustafa Kamil (18741908), Lutfi al-Sayyid (1872-1963) (29), Tāhā Hussain (1889-1973), Ali Abdur Raziq (1888-1996) and Abdullah al-Nadim (1844-1896) were also great admirers of Egypt's past glories and provoked the feelings of Egyptianness; they were well respected intellectuals who held the nationalistic zeal high by their literary works. Some of them were high admirers of pre-Islamic past of Egypt and surpassed the solidarity centering Islam (Ahmad \& Lakhvi, 2015).

Idea of Arab nationalism has a vital role developing nationalism in the Muslim world. Some sociopolitical and intellectual factors are the causes of the emergence of it. The reasons are discussed below:

a) The first element of Arab nationalism is Islam. The early period of success of the Arabs was the success of Islam and it is difficult to divide from each other and the Arab honor and pride absolutely was Islamic. The Arab center of pride and success in Damascus, Baghdad and Cordova was the reflection of the spirit of Islam. So Islam was at early stage a source of inspiration for Arab nationalistic feeling.

b) The early centre of Islamic civilization was situated in the area of Arab speaking land except Delhi, Cordova and Istanbul. Some Arabs thought that the centre of Islam must be in Arabic speaking land so they do not accept the transfer of the centre of Muslim Khilafat from Arab land (Baghdad) to Istanbul though Islam does not permit any kind of supremacy of Arab over non-Arab. But transferring the centre of Islam (actually symbolic) slightly hurt them and they thought about Arab pride through the prism of Islam and started to think about primacy of Arab, it was a paradox of thinking indeed (Donohue and Esposito,1982) .

c) In nineteenth century British and France imperialist power wanted to break down the Turkish empire and to de-integrate the centre of Islam from Istanbul for weakening Muslim power and Turkey Khilafat and they provoked the 
Arab nationalism in many Arab centre for example Damascus, Cairo, Medina, Baghdad and so on. They promised to Sharif Husain of Saudi Arabia to set up an Arab state in Zajeeratul Arab for Arabs only. It was an imperialist tactic but it helped to break down the Turkish Khilafat and sow a seed of Arab nationalism.

d) Some intellectual elements helped to the rise of Arab nationalism. Nasif Yazizi (1800-1883), Batrus Bustani (1809-1883) and Abdur Rahman Al Kwākebi (1849-1903) played a vital role to spread the ethno-linguistic idea of Arab nationalism simultaneously with secularism. They were also inspired by the history of the French revolution as they had the direct experience with invasion of Egypt by Napoleon Bonaparte. It was the secularism dominated nationalism that is advocated for dual entity of social life-religious and political centered on the idea of Catholic Christianity 'give God his due and the Czar's his due'.

e) Some political leaders and parties took European idea of nationalism as the means and weapons for the liberation struggle from the clinch of AngloFrench imperialism. The nationalistic leaders like Habib Borguiba in Tunisia, Benbellah in Algeria, Jamal Abdul Nasser in Egypt promised to the people that after the freedom struggle, they (people) will be awarded with just, rightful, democratic state with economic emancipation. Some of the autocratic and repressive rulers used European nationalism to deceive the people in the face of their unabated corruption, misrule, oppression and for lasting absolute tyrannical power, mentionable among them are Jamal Abdul Nasser, Hafez Al Assad, Saddam Husain, Ben Ali, and Gaddafi and so on.

f) Nationalistic feeling got powerful on the eve of western plot to establish an illegitimate artificial state of Israel in the Arab land by the Belfour declaration (1917) and it was established in the 1948 by the Western powers. Millions of Arabs were uprooted from their original fatherland and they started a struggle to free the land from Israeli occupation. It also struck the hearts and mind of Arab people and united them behind Palestine cause. It consolidated and fomented Arab unity that is still kindling the light of Arab nationalistic feeling. But some Arab leaders knifed back the Arab people by doing many blunders, some of them now cooperating Israel for defeating Palestinian people forever.

g) Formation of Arab league (Est-1945) is one of the physical outcome of the Arab nationalistic feeling. The leaders of the Arab states hoped that it would 
create solidarity and integrity among Arab people to realize their rights and interest in the world perspective. But considering present world system, Arab league is the most ineffective and nonfunctional trans-state organization over the world. It is now called the 'Arab Summit' as the pleasure trip for the heads of Arab states.

It is the pros and cons of the story of Arab nationalism. Arab, Turkish and Egyptian nationalism is a total failure. They failed to provide democracy, rights, justice and economic emancipation for millions of general people. Now it has become a dogma for deceiving people by worst tyrannical rulers of the Arab world. The Kemalist in Turkey and Nasserist nationalism in Egypt are, in the end, surpassing the people's emotion and feeling for Islam. Some of their critics argued that they ultimately deny any space for Islam in the society. Both of them were romantic and despotic in nature. The Arab people are faded, frustrated, and angry with such kind of nationalism that has also failed to unite and integrate the people's hope and aspiration within a state boundary. Their furious anger is observed in the agitation of Arab spring recently (2011). There are various types of schisms and divisions that have torn up and thrown them in total chaos and anomie. Arab nationalism completely failed to give them any common politico-social identity that can unite them under a common umbrella of geopolitical and socio-cultural identity. As a result people specially the youths are searching for alternative. In the other part of the world, for example in Turkey nationalism was not able to integrate the mind and hope of the people at all.

2. Muslim Nationalism or Global Ummatic Nationalism: Muslim Nationalism is a mixed form of historical collective experiences ruled under imperialism and local rival faith community, own tradition, aspiration of finding a political identity and of course transforming the experience of European nationalism, it can be said a bit Islamization of modern nationalism. It was born in British ruled Indian Subcontinent and the philosophical originator was the great poet and philosopher Allama Iqbal. They were influenced in part by Mohammad Abduhu, Jamal al Din Afghani and weakening Turkish Khilafat of late nineteenth century AD. Iqbal believed 'Your strength is Oneness of God, your country is Islam, You, Muslims, are followers of Prophet Muhammad' (Bang i Dara). He also prayed for 'May all the Muslims from the bank of Nile to the land of Kashghar get united for the defense of Haram (Ka'ba)' (Bang i Dara). The great poet dreamt a trans-boundary nation constituted of Muslims over the world by the Muslims who may live anywhere of the world. He deducted the idea of Muslim nation state from the trans-boundary idea of Muslim nationality and Pakistan would be the ultimate existence of the dreamt nation for Muslims.

The socio-political causes of Muslim nationalism were: 
a) Historical experience of sociopolitical discrimination: The late $19^{\text {th }}$ century and the early twentieth century Muslims - the scholars, politically conscious educated class, especially the western educated youths found that they were discriminated by the imperialist oppressive regime and at the same time dominated and discriminated by the opponent faith community in their homeland. That circumstance created one kind of communicative rationality in the Muslim Mind and they thought that their own faith-based nation would be their final political and social destination.

b) Philosophical explanation: Some philosophers dreamt that as Islam is the social philosophy and system, it needed to form a state for fulfillment of Muslim hopes and aspirations in the statehood that would provide the state service in their homeland and oversee the world Muslim affairs in international level. They were advocating for Muslim state and nationhood and inspiring Muslim youths struggling for that dreamt state.

c) At that period of colonial and imperialist invasion Muslims found that they were oppressed and suppressed because they are Muslim in the global perspective so Muslim rationality is reorganized in the face of adverse situation.

d) Some Muslim thinkers found that geopolitical and ethnic (language based) nationalism was introduced in the Muslim society by the western colonials for making division and schism in the Muslim society to gain political benefits by weakening the existing Muslim Ummah and to get future political benefits from the chaos and conflicts that will arise from the nationalism (now the westerns are getting hundred percent) in future. That is why they (Muslim thinkers) were preaching Muslim Nationalism and opposing geopolitical and ethnic nationalism.

e) Some Muslim leaders, a number of Ulemas, took Muslim nationalistic feeling simply as the weapon to fight the chain of colonialism and imperialism in Asia, Africa and the Middle East. But when they got their long cherished Muslim state, some of them got frustrated with the consequences.

f) Nowadays, a large number of Muslim thinkers and youths believe in transboundary Muslim nationalism and this kind of thinking flourishes in two way processes: (1) they experienced that western geopolitical and ethnic nationalism utterly failed in the Muslim world. The state achieved for the unimaginable sacrifice of lives and blood was confined to the hands of the rulers and elites who are absolutely corrupt, totalitarian, autocrats and poodles of western neocolonist powers and again they remake their thinking and rationality and tend to 
Muslim trans-boundary nationalism as a solution; (2) they experienced that the geopolitical and ethnic nationalism failed to integrate the state and the people as a whole. The state was further disintegrated by territorial and ethnic conflicts. Sometimes real conflicts of group interests were the cause, sometimes the conflicts plotted by the outside interest groups or entity (state/states) e.g. in Sudan, Iraq, and Turkey and so on. By observing those realities a significant number of Muslim youths think alternatively and one of them is the idea of global Muslim nationalism or Umamatic Nationalism. Because they found that in reality geopolitical and ethnic nationalism in the Muslim world is a story of complete failure.

The evolution of the above mentioned thinking started from global Muslim nationalism to homeland based Muslim state nationalism (Pakistan) and again turned (on the eve of $21^{\text {st }}$ century) to global trans-boundary Muslim nationalism or Umamatic idea of nationalism. Now, it is getting momentum among the youths over all parts of the world.

3. Nationalism not accepted by some people at all: Their hypothesis based on the reasons is given bellow:

a) Islam is not a basis of nationality, rather it is an ideology, system of beliefs, program for achieving a mission for humanity, a complete guidance for human life that is to make with its followers a visionary global trans-boundary organization like brass built wall. It will prevail beyond all other group identities that come from kinship, clan, tribe, blood relation, ethnicity, race, territorial entity, statehood and administrative unity or so on.

b) Muslim over the world is a single organization centered on principles and vision with same goals to live and to establish a better world for humanity, not to establish a uniform nation that is impossible with various group identities of man that should be respected under Islam.

c) Muslim identity should not be considered in similar fashion with nationality, clan identity, tribal identity, identity on linguistics, ethnicity, race, identity based on territory and community. It is a membership in a modern organization which has a goal, mission, vision, constitution, beliefs, values and moralities. It is a (Muslim) universal identity for the believers who can retain his other identity feeling for especial occasion (eating, dressing, social calibration with simplicity and modesty, not surpassing the system of core values and beliefs of Islam directly or indirectly) but not to take as pivotal focus and goal. 
d) Nationhood (in modern western meaning) is totally harmful for Islam itself and its goals because nationhood is established on national pride and enviousness to other nations, love for won and hatred for other nations. One of the political mainstays in modern world is hate campaign to other nations that is unacceptable to Islam. If there is no conflicting mindset, interests, hegemony, competition and conflict for resources, social, psychological and strategic tug of war, there is no reason for a separate state. Sometimes political leadership creates and maintains false pride and hatred in the mind of people for their (leaders) rationality of being leader and retaining power base untainted so that nationalism in any form should not be Islamized.

Some people may question that some things are not clear in this thesis; these are: What is the explanation of being many states in the Muslim Society? How do they (states in Muslim society) resolve their argumentative interests? Whether the organization of ideal type will exist with sovereignty or not? How do they represent world Muslims in global forum e.g. UN, WB, WTO for Muslims' problem and prospects? Whether it will function like a civil society organization? These questions must be answered from these view holders. But I think it is one of the soft views that may open the door for future debate for how Muslims can retain their identity and adapt in the face of modern nationhood with majority and minority status under modern state in the globalized world.

Some scholars observe that Nationalism meaning national interest is not against Islam. Scholars now agree that there can be many states in the Ummah. However the bases of these states have to be Qur'an and Sunnah. Ummah feeling should be strengthened by education.

What next: What is the way out for the Muslims to resolve this type of socio-political serious crisis? In a pragmatic view Muslims can think about it by considering three important problems of world Muslims. These are: (1) Political identity and statehood; (2) Economic emancipation of Muslims over the world; and (3) Cultural Identity and distinction.

Every collectivity needs a clear-cut definition or sense of communicative rationality to be the member of a particular group. If the members or a part of a group is being obscured about the logic or reason of group membership, then the group is gradually weakened by the loosing of group solidarity. If the Muslims are divided centering the collective identity debates, then the very objectives of what the prophet wished 'all Muslims are like a body' and what Allah mentioned 'all the Muslims are the brothers' will be thrown into futility. A large number of thoughtful young Muslims now live in 
identity crises. Muslim thinkers and sociologists need to resolve it by giving an unambiguous explanation of collective identity of world Muslims in the face of globalization and speedy technological unification of societies. How can the globally communicated young Muslims incorporate the conflicting idea of collective identity or go out from the dilemma? Whether they should try to incorporate all the ideas under a single umbrella of sociopolitical concept or take one from existing concepts or thinking for an alternative one? Time is advancing caring anything and society is changing without respecting our wishful thinking but it is an important thing that they should rationalize with the changing process. No ideology or religion or group or state or any other social institution can cope with the changing process without synchronizing meaningful adaptation.

In our globally changing social world the reality is, a good number of Muslims live in countries with minority status or in some societies they are almost equal in number with other faith based communities. Moreover, Muslims in the majority status cannot disrespect other group identity and culture; it is also not the teaching (to ignore other identity) of Islam. Some Muslim scholars think that the above mentioned crisis should be resolved by taking some scholarly measures in the field of intellectuality because we are convinced that if we want to change our world, we need to change our thinking and rationality first. It would be the way out from the dilemma of identity crisis of Muslim Ummah and the suggested ways to be resolved:

a) State is a politico-legal and sociopolitical entity and without state politicolegal life is impossible. Islam is not an expansionist, aggressive and revolutionist ideology and it is law abiding in nature. The physical mobilization and taking some necessary services from local and global institutions are not possible without citizenship under a state that is why the Muslim may take the citizenship as a politico-legal reality. The prophet loved his fatherland with deep feeling but that land was not Islamic before the majority of Makkan people embraced Islam. He left Makka for pragmatic reasons but never left love and passion for his fatherland-Makka. The Muslim youths also should love their father land for the preaching of Islam though some forces make it impossible for them. Almost all the cases, through the existing legal procedure dawah (calling people into Islam) activities are possible by the supremacy of virtuous behavior and attractive personality. With a few exceptions, a good behaved person is always welcomed by others irrespective of their creed and culture. Within legal framework a devoted Muslim can preach his ideology to the non-believers without breaking the 
existing law of a land. So siding the hard hitting debate of nationality a Muslim can take matter as politico-legal matter and make contribution for his fatherland, his contribution, it may be intellectual or by employing skills or any other forms. One contribution earns him recognition and by the recognition he can uphold the value, beliefs and preaching. Then I think there will be no identity crisis.

If any group term them as outsiders or any other manner then everyone should know that where a person is born is his homeland, where he gives his labor is his own land, where he employs his skills and merit is his own land because the earth is not the civilization itself, the present civilization is the outcome of labor and merits of human being. So, where a person employs his labor and creativity is his land.

b) Economic activities actually mean in sociology to adapt with the physical environment by producing and consuming things. It has many dimensions: community aspect, local and regional, national and international, etc. Even a single person is not fully separated from the world economic system in the modern age. A group, a community, an organization or a nation cannot survive for long over the world without trans-state and trans-national connectivity. If the Muslims want to reach every corner of the world with their mission of peace, welfare and justice, they must have to be economically solvent and every member of the society to be an entrepreneur, producer, technocrat or a technology inventor. If they become so, then they will be able to influence significantly the world economic system, not for their favor but for the favor of economic justice and welfare of humanity, that is one of the missions of Muslims over the earth as representative of Allah.

Considering these circumstances, Muslims should play an active role wherever they are placed in, try to uphold the economic system, by contributing maximum, in favor of economic justice and welfare and that will speed up cooperation among them and strengthen solidarity in the end. Moreover, that will enhance their integration and solidification; as a result there will be no identity crisis in future. The Muslim majority states can try to enhance their internal trade and exchange that will bring them near to nearer and all the closeness among the same category of people will bring significant benefit for all. The more closeness and mutual cooperation in productive activity brings the world Muslim close to closer and enhance their economic ability in global 
stage and as a result world Muslims will gradually habituate to think they all are brothers of a same global community.

c) Culture is the key dimension of the society that actually makes society stronger, functional and dynamic. Culture provides belief, value and morality which are the energy and force for group dynamism. When we talk about the European value and behavioral standards, actually we talk about ultimate value of Christianity. Sociologist Jurgen Habermas pointed that without explaining core religious value and morality we cannot explain the larger society. He opined that the present European social value and pattern of behavior is the outcome of core Jewish value of justice and Christian value of love.

Now Muslim Society needs to determine the core value and behavioral pattern of Muslim society. For example, simplicity, equitable treatment in behaving, kindness, justice, respect for others' prestige, personality and property, and equality to all can be identified as the core value of Islamic culture. Islam has various social components functioning as the tools of solidification and unification of Muslim mind and thinking process and those lead them in expected route towards the final goal. For example, Hajj, Salat, Siam, idea of equality, simplicity and kindness are the values and practices; these are functioning for achieving the specified goal. If it would be the image of a Muslim Youth in Non Muslim society like that, he never told a lie, never foraged anyone, never took alcohol and drugs, never did unnatural and extramarital sex. If he is laborious, hardworking, innovation prone, tolerant, kind and rational then it would be considered the best identity for anyone in any society over the world and that is the dreamt social identity for a person in the eye of the prophet.

Today's Muslim scholars and intellectuals should actively think how culture and daily behavioral pattern of Muslims, their involvement, interaction and interrelationship make them global citizens, better citizens, good neighbors, cooperative colleagues, delightful partners, caring associates, responsible co-workers and finally good men. Through the unification of lifestyle, making more uniformity of behavioral pattern, retaining same value standard in the mind and thinking, responding logically in the face of debacle, expressing delight with smile, celebrating win in perfect rationality world Muslims can receive a distinctive identity that will make them confident enough and that will remove the identity crises from their mind and thinking. They will become bold and beautiful in the drama stage of the human society. 


\section{References}

Ahmad, H. \& Lakhvi, M. H. (2015). A Glimpse of the History of Nationalism in the Muslim World, Punjab: University of Management Technology.

Ali, Shaukat. (2004). Islam and the Challenges of Modernity: An Agenda of Twenty First Century, Islamabad: National Institute of History and Cultural Research.

Bottomore, T. B. (1994). Sociology, Political Sociology, Bombay: B L Publications.

Bryce, J. (2008). Modern Democracies, New York: Cosimo Inc.

Bazzaz, Abd Ar-Rahman and Sylvia G. Haim. (1954). Islam and Arab Nationalism, http://www.jstor.org/

Donohue and Esposito. (1982). Islam in Transition: Muslim Perspective, New York: Oxford University Press.

Iqbal, M. (1960). Reconstruction of Religious Thought in Islam, Lahore: Ashraf Pres.

Laski, H. J. (1925). A Grammar of Politics, London: George Allen \& Unwin Ltd.

Kohn, Hans. (1944). The Idea of Nationalism: A Study in its Origins and Background, Toronto: Collier Books.

Maududi, S. A. A. (1986). Islam and Nationalism (Bengali- Islam o Zatiotabad, original book- The Question of Nationalism, 1939) Dhaka: Adhunik Prakashani.

Naqvi, A. M. (1985). Islam and Nationalism, London: Islamic Propagation Organization. al-islam.org.

Masud, Muhammad Khalid et al. (2009). Islam and Modernity, Edinburgh: Edinburgh University Press

MacIver, R. M. (2005). Politics and Society, New York: Aldine Transaction

Rahman, F. (1984). Islam and Modernity, London: The University of Chicago Press.

Shabbir, G. (2010). The Crossed Swords: Islam, Modernity and Fundamentalism, Karachi: University of Karachi.

Swain, J. E. (1994). A History of World Civilization, New Delhi: Eurasia Publishing House.

Zaman, N. et al. (2012). Islam and Nationalism: A Contemporary View, Interdisciplinary Journal of Contemporary Research in Business, Islamabad: Vol. 4, No. 5. 